\title{
Libraries in Sri Lanka in the Ancient Anuradhapura Period: a Historical Account (250 B.C. - 1017 A.D.)
}

Ranaweera, R.A.A.S ${ }^{1}$ and Ranasinghe, Piyadasa ${ }^{2}$

\begin{abstract}
The origin of libraries in Sri Lanka is related to the introduction of Buddhism to the Island. Buddhism was formally introduced to Sri Lanka by Venerable Mahinda, in the third century B.C. during the reign of King Devanampiyatissa. The advent of Arahant Mahinda and Arahant Sangamimtha to the country during the ancient Anurādhapura era was considered as major landmark in history. The art of literary tradition and bibliographic activities properly began in the ancient Sri Lankan history with these two important events. Education also was enriched by the influence of Buddhism during the Anurādhapura period. There were three main learning centers for monks in ancient Sri Lanka namely the Mahavihara, the Abhayagiri and the Jetavana. It was quite possible that these religious and educational centers possess repositories of books or may be simply known as libraries. Recorded evidence available in the Mahawamsa and Culawamsa showed that there had been large numbers of monastic libraries in ancient Sri Lanka but it is difficult to find recorded evidence of these early types of libraries, except for the written facts available in early literature regarding their existence.
\end{abstract}

Keywords: Anuradhapura period, Monastic Libraries, Mahaviharaya, Abayagiriya, Jetavanaramaya,Mahawamsa, Culawamsa

\section{Introduction}

Anurādhapura, the ancient citadel of Sri Lanka is more or less the heart and soul of the religious and cultural heritage of Sri Lanka. Richly bestowed in such traditions, like architecture which paved the way to build massive buildings and structures such as the Ruwanweli Dagaba takes place of prominence in the era .It could be said that the economy and culture reached a pinnacle of existence during the rule of the great kings and the golden age of Buddhism also existed during this period.

\footnotetext{
${ }^{1}$ Corresponding author:

Assistant Librarian, University of Kelaniya, Sri Lanka. Email: achala@kln.ac.lk

${ }^{2}$ Senior Lecturer, Dept.of Library and Information Sciences, University of Kelaniya, Sri Lanka.Email: priyarana@kln.ac.lk
} 
According to Seneviratne (1994) the origin of the city of Anurādhapura dates back to the $4^{\text {th }}$ century B.C. It was the capital of the Anurādhapura Kingdom. He further states that Anurādhapura also a wealthy city which created a unique culture and a great civilization. Today this ancient city of Sri Lanka, which is sacred to the Buddhist world, with its surrounding monasteries covers an area of over sixteen square miles (40 sq. km.) and is one of the world's major archaeological sites (p. 13).

Ceylon has an ancient literary and library tradition. According to De Silva "Writing was known to Singhalese from the earliest time but no books or records of this period have been found"(1938,p.xiii). Literary activity in Ceylon can be traced from the period of king Vijaya (483 B.C.). The seventh chapter of Mahavamsa showed evidence about writing and documentation during the period of King Vijaya. It says that there was a letter sent to king Pandi in India from Ceylon for requesting to find a suitable partner, a queen for king Vijaya from a kshathriya family. This incident undoubtedly proved of existence of written communication system and documentation methods of ancient Ceylon.

Buddhism was introduced to Ceylon in 300 B.C. during the reign of king Devenampiyatissa (250-210 B.C.) (Seneviratne,1994). Influence of Buddhism towards social, political, cultural, economical and educational activities of ancient Anuradhapura period was remarkable.

Reputation of the literary activities in ancient Ceylon had extended to other neighbouring countries such as South India, Burma and China. Buddhist monks were came to study literature on Buddhism and took away copies of Buddhist Text and Commentaries to their countries. Visits of Buddhadatta Thero and Buddhagosha Thero around the early parts of the fifth century A.D. proved the states of account of wealthy literature tradition in ancient Anurādhapura period.

The teachings of Lord Buddha preached by the Arahant Mahinda were well preserved by the Sanga or the Buddhist monks by oral tradition from generations to generations over successive periods of time (Adikaram,1953). The teachings of Buddha or the Tripitaka 
were committed to writing on ola leaves at the time of King Valagamba or Vattagamini Abhaya (103-77 B.C.) at the 'AluVihare' in Matale during the first century B.C. This is one of the remarkable features of the literary and library tradition in Sri Lanka and also the establishment of libraries in Sri Lanka. It is evident that documentation was systematically commenced with this historical event. The copies of those written Tripitaka texts were supposed to have been deposited in all the leading temples in the island and it was an excellent instance for dissemination of knowledge in ancient Sri Lanka.

Royal patronage was given in a great way to establish literary and library activities during the ancient Anurādhapura era. Most of the kings who ruled this period donated lands for building monasteries. Also some of the veteran kings such as King Buddhadasa (337-365 A.D.),King Kumaradasa (508-516 A.D.) and King Sena I (835-853 A.D.) had written books on various subjects including drama, astrology, poetry and medicine. These books would have been preserved in the libraries attached to monasteries and royal libraries during the Anuradhapura kingdom.

\section{Objective}

The main objective of this historical research is to explore the existing of library and library tradition in the ancient Anurādhapura period.

\section{Related Literature}

There is no doubt that the library tradition of early Sri Lanka started in the monastic libraries. The Ceylonese chronicles Deepawamsa, Mahawamsa and contemporary sources give some of the details about early literature activities which took place in the ancient Anurādhapura era.

Recorded evidence available in the Mahawamsa and Culawamsa showed that there had been large numbers of monastic libraries in ancient Sri Lanka but it is difficult to find evidence of these early types of libraries, except for the fact of their existence. Culavamsa gives information on a library (Potthakalaya) attached to the Jetavana Viharaya. 
Harold V. Bonny, UNESCO library adviser mentioned in his report on 'Library Services for Ceylon' (1962?) as follows “Librarianship in Ceylon is indigenous. It is not something to be implanted from abroad: it already exists-by tradition in your Temples with the Ola leaf manuscripts" (p.4).

Piyadasa states that terms such as " "Bhandarapotthakin and "Adipotthakin" have been used at that time to mean certain professional positions. Paranavithana is in the opinion that the terms "Pota" found on the Sigiriya Graffiti may be equated with "Potthakin" which means "a keeper of books". If so, "Bhandarapotthakin" may be equated to the position of that of a Chief Keeper of books and "Adhipotthakin" to mean a Director of libraries" (1985, p.14).

\section{Research Methodology}

This research is highly based on historical and archival data obtained from secondary data sources. Data were mainly collected through information sources available in the National Archives Department and Museum Library.

\section{Significance of the Study}

Quite a few studies have been done on historical aspects of libraries in Sri Lanka. This study explores the library tradition and royal patronage was given to the development of library tradition practiced in ancient Anurādhapura Era.

\section{Libraries in the Ancient Anuradhapura Era (250 B.C. - 1017 A.D.)}

The great Ceylonese chronicle the Mahawamsa shows evidences on ancient libraries functioned in the Anurādhapura era. The Mahawamsa gives information on several pirivenas or the Buddhist learning centers granted to the Venerable Mahinda Thero by King Devanampiyatissa as follows:

"...And in the very first days the king commanded that a pasada be built for the there in the Tissarama, and he had the bricks of clay dried speedily with 
fire. The dwelling-house was dark-coloured and therefore they named it the Kalapasada-parivena. He built many parivenas in an excellent manner" (Mahawamsa,1950, p.112-113).

Mahawamsa further states that king Devanampiyatissa had built network of parivenas during his regime in the Anuradhapura kingdom. Sunhataparivena, Digha-cankamana, Phalagga-parivena, Therapassaya-parivena and Marugana-parivenawere among them. Following the footsteps of the great king, the commander of the king's troops, Dighasandana, built a little pasada for the Arahant Mahinda with eight great pillars called the Dighasandasenapati-parivena (1950, p.112-113).

It was quite possible that these parivenas or the Buddhist learning centers were built to accommodate monks however it could be assumed that learning activities may also took placed to a cretin extend. During the later part of the Anurādhapura kingdom the Mahavihara became the main centre for Theravada Buddhism and most probably there would have been a library attached to it for the use of monks. Not only the Mahavihara, but the Abhayagiri Vihara and Jetavana Vihara, became the centres of learning for the monks. It is possible that these Viharas would have been like the universities of today (Corea, 1969, p.1205).

It is very clear that royal support was always given to development of literature activities, building of preaching halls, pirivenas and libraries by most of the kings who ruled the country during the Anurādhapura era. According to the Mahawamsa the great King Dutugamunu (163-137 B.C.) had built a number of preaching halls and treated the Buddhist monks in a great manner. He had recorded all his charity works in a book called 'pin potha' or the 'book of meritorious deeds'. The book says King Dutugamunu had built ninety nine viharas, and he had ordered that Buddhist doctrines be preached in every temple in Sri Lanka. Also the book of 'meritorious deeds' says that he had given rewards to the preachers (Mahawamsa, 1950, p.222). 
"...Since then I have commanded the preaching of the doctrine everywhere, in the viharas of Lanka, giving rewards to the preachers. To each preacher of the doctrine did I order to give a nail of butter, molasses and sugar ; moreover, I bestowed on them a handful of liquorices, four inches long, and I gave them moreover, a pair of garments" (ibid,p.223-224).

During the reign of the King Vattagamini Abhaya (103-77 B.C.) the oral tradition of the Tripitaka was committed to writing at AluViharaya in Matale by the monks.

"The text of the three pitakas and atthakatha thereon did the most wise bhikkhus hand down in former times orally, but since they saw that the people were falling away (from religion) the bhikkhus came together, and in order that the true doctrine might endure, they wrote them in books. Thus the king VattagaminiAbhaya reign twelve years..."(Mahawamsa, 1950, p.237).

This is one of the most remarkable events of the literary tradition and also the establishment of libraries in Sri Lanka. The copies of those written Tripitaka texts were supposed to have been deposited in all the leading temples in the island (Corea, 1969, p.1205).

Almost all the kings who ruled Sri Lanka during the Anurādhapura kingdom gave their utmost support for the development of literary activities and building of libraries all over the country. The Culavamsa shows that King Buddhadasa (337-365A.D) was gave salaries to the Preachers during his reign (1953, p.14).

The arrival of Buddhagosha Thero to Sri Lanka in the reign of King Mahanama (406-428 A.D) is one of the significant events of literary and library tradition in Sri Lanka. It also showed the reputation of the literature activities in Sri Lanka among the neighbouring countries. He came to Sri Lanka to translate the Shinhala Atuvas or the commentaries into Pali. According to the Culavamsa he sojourned at the Ganthakara Vihara or the pirivena attached to the Mahavihara (Culavamsa, 1953, p.25-26). When Buddhaghosa Thero came 
to Ceylon, there already were in the island many collections of commentarial matter preserved mainly in the Singhalese language (Adikaram, 1953, p.10). Before starting the actual literary work he had to prove his skills in the subject. In order to shown his skill and scholarship, he wrote the Visuddhimagga. There is no doubt that Buddhagosha Thero had used many books deposited at the Mahavihara library and the GanthakaraVihara or the pirivena for his literary activities. After considering these facts, we can assume that the Mahavihara had the first well - organized monastic library in ancient Sri Lanka.

The Culavamsa showed royal patronage to the establishment of libraries in the Anurādhapura era. King Kassapa I (473-491 A.D.), King Moggollana II (531-551 A.D.), King Sena II (853-887 A.D) had given their support to writing of the doctrine and preserving them in pirivenas all over the country (Culavamsa, 1953). It is said in the Culavamsa that King Kassapa V (914-923 A.D.) "had the Abhidhamma-pitaka written on tablets of gold, the book Dhammasangani, adorned with all kinds of jewels, and having built a splendid temple in the midst of the town he placed the book in it. The position of Sakkasenapati he granted to his own son and entrusted him with the care of this sacred book" (ibid, p.167).

The three main libraries attached to the three important centres of Buddhist learning, namely the Mahavihara, the Abhayagiri and the Jetavanawere in an eminent place during the Anuradhapura period. Books on Theravada and Vaitulayavada must have been available in these libraries. We can also assume that the Dighsan-dasenapatipirivena, where Mahanama Thero, author of the Mahavamsa dwelt, and the Ganthakara - vihara, where Buddhaghosa Thero lived and worked, possessed two important libraries. The libraries of Uttaramula and Kappuramula at Abhayagiri would have occupied important places during the Anurādhapura period (Kularatne, 1975, p.195).

Also some of the veteran kings had written books on various subjects during the Anurādhapura period. Sararthasangrahaya by King Buddhadasa (337-365 A.D.), Jaanakiharana by King Kumaradasa (508-516 A.D.), Siyabaslakara by King Sena I(835-853 A.D.) and Dhampiya Atuwa Gatapadaya by King Kashayapa $V$ were well-known literary 
works among them. These books would have been preserved in the libraries attached to monasteries and royal libraries during the Anurādhapura kingdom (Ranasinghe, 2006, p.118, text in Shinhala).

Though the literary activities and libraries were in a stable position there were destructions that occurred from time to time during the Anurādhapura period. Many books and libraries were destroyed specially the dissensions between Mahaviharaya and Abayagiriya by innumerable foreign invasions, which caused political instability during the reign of various kings (Corea, 1969, p.1206).

\section{Summary}

According to the gathered literature, it is evident that early libraries of Sri Lanka were started in the monasteries with the influence of Buddhism. It is very clear that the literary activities and libraries were maintained in an excellent manner during the ancient Anuradhapura period. It was also visible that education was enriched by the influence of Buddhism during the ancient Anuradhapura era. The three main libraries attached to the Mahavihara, the Abhayagiri and the Jetavana were performed an excellent service in order to develop the literary activities and library tradition during the ancient Anurādhapura period. Findings of this research showed that unlike the later eras, Buddhist monks and high ranking officials were the main users of monastic libraries functioned in the period of Anurādhapura kingdom. During the later eras of ancient Sri Lanka, specially in Kotte period, monastic libraries were also open for laymen. Visits by foreign scholarly monks such as Buddhadatta Thero and Buddhagosha Thero proved the degree of popularity of literary activities and libraries among the neighbouring countries.

The royal patronages granted for the development of literary activities and libraries during the ancient Anurādhapura kingdom were significant. Most of the kings who ruled ancient Anurādhapura era gave their utmost support and contributed towards the endowment of Buddhist monks, monasteries and the libraries attached to those. Kings such as Buddhadasa, Kumaradasa and Senal directly engaged with literary activities by writing 
books in the Anuradhapura period. In summary it is clear that as a result of these reasons the literary activities and libraries were in an excellent condition during the ancient Anuradhapura period.

\section{References}

Adikaram, E.W. (1953). Early history of Buddhism in Ceylon. Colombo: Gunesena.

Bonny, H.V. (1962?). Library services for Ceylon. Colombo: Department of Cultural Affairs.

Bowden,R.(2011).Sri Lanka's earliest libraries-Anuradhapura and Pollonnaruwa period, Sri Lankan Journal of Librarianship and Information Management,[online],Vol.4(3-4),p.158,Available at:http://192.248.17.88/nilis/images/journal/v4_2/Russell.pdf,[accessed 10 August 2013]

Corea, I. (1969), Library Services, In Education in Ceylon (from the sixth century B.C. to the present day) : a centenary volume, Ministry of Education and Cultural Affairs, Colombo

Culavamsa.(1953), Geigher,W. (tr.)., London: The Pali Text Society.

De Silva, W.A. (1938).Catalogue of palm leaf manuscripts. Colombo: Government Press.

Kularatne ,T. (1975). History of libraries in Sri Lanka, In Corea, I. (ed.) ,Libraries and people: Colombo public library 1925 - 1975. a commemorative volume, Colombo Public Library, Colombo

Mahawamsa (1950),Geigher,W. (tr.), Reprint., Ceylon Government Information Department,Colombo

Piyadasa,T.G. (1985). Libraries in Sri Lanka: their origin and history from ancient times to the present tim. Delhi : Sri Satguru Publications.

Ranasinghe,R.H.I.S .(2006).Pereni lankawe pothgul sampradhaya: kristupurwa hayawana siyawase sita kristupurwa dahatun wana siyawase dakw., Kelaniya: Author.

Seneviratne, A. (1994). Ancient Anuradhapura. Colombo: Archaeological Survey Department 
Journal of the University Librarians Association of Sri Lanka, Vol.17, Issue 1, January 2013

Tissa,R.D.A.(2012). Noothana pustakala ha winggnapana vidya wurtiyehi padanama bauddha sambawaya sahaithaya asuren nirikshanayakirima. Sri Lanka Library Review, 26.

Note:

Abstract of this paper presented at the International Conference on Asian Art, Culture and Heritage held on $21^{\text {st }}-23^{\text {rd }}$ August, 2013 at the Sri Lanka Foundation Institute, Colombo, Sri Lanka. Abstract is available in page. 137 